\title{
SOCIAL JUSTICE ON ENVIRONMENTAL LAW ENFORCEMENT IN INDONESIA: THE CONTEMPORARY AND CONTROVESIAL CASES
}

\author{
Adiguna Bagas Waskito Aji \\ Justice for Environment Forum \\ Puji Wiyatno \\ Faculty of Law, Universitas Negeri Semarang, Indonesia \\ Ridwan Arifin \\ Faculty of Law, Universitas Negeri Semarang, Indonesia \\ Ubaidillah Kamal \\ Faculty of Law, Universitas Negeri Semarang, Indonesia \\ Email: adigunabagas@gmail.com
}

This paper discusses Social Justice in the context of the Environment, where the basic legal framework underlying the development and protection of Indonesia's environment is contained in the opening of the 1945 Constitution in paragraph 4, which in essence requires the government to utilize natural resources for as much -lots of people's welfare. Thought about the constitutional obligations of the state are further elaborated in Article 33 of the 1945 Constitution, namely the principle of the state, the earth and all the wealth contained therein and the livelihoods of the people controlled by the state to be used for the lives of many people or with the word other countries act as organizers of public interests. A good and healthy environment is the human rights of every Indonesian citizen as stated in Article $28 \mathrm{H}$ of the 1945 Constitution of the Republic of Indonesia.

Keywords: Environmental Justice; Social Justice; Environmental Law; Law Enforcement

The Indonesian Journal of International Clinical Legal Education DOI: 10.15294/ijicle.v2il.37324

https://journal.unnes.ac.id/sju/index.php/iccle

C 2020 Authors. This work is licensed under a Creative Commons Attribution-

ShareAlike 4.0 International License. All writings published in this journal are personal views of the authors and do not represent the views of this journal and the author's affiliated institutions.

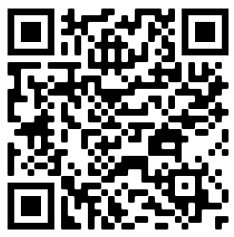




\section{PENDAHULUAN}

Lingkungan hidup sebagai karunia dan rahmat Tuhan Yang Maha Kuasa kepada rakyat dan bangsa Indonesia merupakan ruang bagi kehidupan dalam segala aspek dan materinya sesuai dengan wawasan nusantara. Dalam rangka mendayagunakan sumber daya alam untuk memajukan kesejahteraan umum seperti diamanatkan dalam Undang-Undang Dasar 1945 dan untuk mencapai kebahagiaan hidup berdasarkan Pancasila. ${ }^{1}$

Kaidah dasar yang melandasi pembangunan dan perlindungan lingkungan hidup Indonesia terdapat dalam pembukaan Undang-Undang Dasar 1945 pada alinea ke-4 yang pada pokoknya mewajibkan pemerintah untuk mendayagunakan sumber daya alam yang ada untuk sebanyak-banyak kesejahteraan rakyat. Pemikiran tentang kewajiban negara ini secara konstitusional tersebut lebih dijabarkan lagi dalam Pasal 33 Undang-Undang Dasar 1945, yaitu prinsip negara, bumi dan segala kekayaan yang terkandung di dalamnya serta menjadi hajat hidup orang banyak dikuasai oleh negara untuk digunakan untuk kehidupan orang banyak atau dengan kata lain negara bertindak sebagai penyelenggara kepentingan umum. ${ }^{2}$ Lingkungan hidup yang baik dan sehat meruoakan hak asasi setiap warga negara Indonesia sebagaimana diamantkan dalam Pasal 28H UUD RI 1945. ${ }^{3}$

Masalah lingkungan hidup secara formil baru menjadi perhatian dunia setelah terselenggaranya Konferensi Perserikatan Bangsa-Bangsa (PBB) tentang lingkungan hidup, yang diselenggarakan pada tanggal 5 sampai 16 Juni 1972 di Stockholm Swedia, terkenal dengan United Nations Conference on Human Environment. The Convention provides that the coastal state may exercise over the continental shelf sovereign rights for the purpose of exploring it and exploiting its natural resources. The rights are exclusive and do not depend on occupation or any express proclamation. The coastal state has exclusive rights to authorize and regulate drilling on the shelf for all purposes. ${ }^{4}$ Konferensi berhasil melahirkan kesepakatan internasional dalam menangani masalah lingkungan hidup, dan mengembangkan hukum lingkungan hidup baik pada tingkat nasional, regional, maupun internasional. ${ }^{5}$

Perusakan habitat sumber daya hayati melalui berbagai cara yang tidak wajar, bukan saja berakibat buruk pada sumber daya hayatinya

1 Siswanto Sunarso, Hukum Pidana Lingkungan Hidup dan Strategi Penyelesaian Sengketa, Indonesia, Rineka Cipta, Jakarta, 2005, hal. 1.

2 Syahrul Machmud, Problematika Penerapan Delik Formil Dalam Perspektif Penegakan Hukum Pidana Lingkungan Di Indonesia, Indonesia, Mandar Maju, Bandung, 2012, hal 106.

3 Sudi Fahmi, Asas Tanggung Jawab Negara Sebagai Dasar Pelaksanaan Perlindungan dan Pengelolaan Lingkungan Hidup, Jurnal Hukum, Vol. 18 No. 2 April 2011, hlm. 212-228.

4 Kenneth Palmer, "Environmental Management of Oil and Gas Activities in the Exclusive Economic Zone and Continental Shelf of New Zealand" Vol. 31, No. 2, J.

5 Ibid, hal.1. 
(hutan mangrove, terumbu karang, ikan dan sebagainya) yang berakibat pada pemusnahan plasma nutfah, juga telah membawa akibat pada penurunan pendapatan masyarakatnya.

Berbagai kegiatan pembangunan yang berlangsung di kawasan pantai dan pesisir seperti pembangunan pelabuhan, industri, perumahan, pariwisata, pertambangan dan perikanan memunculkan berbagai isu dan masalah sebagai hasil dari penggunaan dan pemanfaatannya serta konflik kepentingan antara berbagai pihak. Selama tahun 1984-1997 saja misalnya laju kerusakan hutan sudah mencapai 16,57 juta hektar pertahun. Ini berarti bahwa setiap tahun ada sekitar 2.586.500 hektar hutan yang rusak. Selain itu kebakaran dan pembakaran hutan selang 1997-1998 telah menghabiskan kurang lebih 10 juta hektar hutan. Pendirian suatu pabrik atau perusahaan dalam suatu ekosistem tertentu akan mempunyai korban pada lingkungan hidup sekitar. Pada awal pembuatan bangunan paling tidak akan membawa pengaruh pada perubahan lahan yang mengakibatkan perataan pohon-pohon dan terganggunya stuktur tanah sekeliling. Kasus pencemaran dan perusakan lingkungan ini adalah sangat berbahaya bagi kesejahteraan umat manusia. Apalagi pencemaran dan perusakan lingkungan di lakukan oleh perusahaan-perusahaan yang bergerak dalam berbagai bidang kegiatan, baik itu pertambangan, kehutanan dan lain-lain.

\section{FAKTOR PENYEBAB TERJADINYA TINDAK PIDANA LINGKUNGAN}

Jika kita berbicara tindak pidana lingkungan hidup maka tidak akan terlepas pada asas ultimum remedium yang dianut dalam UndangUndang Nomor 32 Tahun 2009 tentang Perlindungan dan Pengelolaan Lingkungan Hidup, asas ini tidak menjelaskan mengapa legislator memperlakukan asas ultimum remedium hanya terhadap baku mutu air limbah, baku mutu emisi dan baku mutu gangguan saja. Padahal karakteristik delik formil baru merupakan pelanggaran administrasi, yaitu berupa pelanggaran syarat atau izin yang ditetapkan. ${ }^{6}$ Kecenderungan memfungsikan hukum pidana dalam masalah lingkungan sebagaiprimum remedium sangat menonjol dibandingkan dengan mendahulukan upaya hukum lain, padahal delik formil lebih dominan dibandingkan dengan delik materil.

UUPPLH lebih menonjolkan pidana penjara bagi pelanggar hukum administrasi yang justru belum melakukan pemcemaran dan/atau perusakan lingkungan. Kejaksaan Agung sebagai salah satu institusi penegak hukum telah membuat sebuah pedoman bagi jajaran kejaksaan dalam menangani kasus lingkungan khusus menyangkut asas subsidaritas dihubungkan dengan delik formil. Pedoman tersebut termuat dalam surat nomor: B-60/E/Ejp/01/2002 tertanggal 29 Januari 2002,

6 Syahrul Machmud, Op Cit, Hal 402. 
perihal pedoman teknis yustitial penanganan perkara tindak pidana lingkungan hidup yang berkaitan dengan asas subsidaritas. ${ }^{7}$ Surat ini ditujukan kepada Kepala Kejaksaan Tinggi Seluruh Indonesia. Pedoman ini memberikan acuan kerja sebelum menerapkan hukum pidana, ini mengandung makna bahwa kegiatan penegakan hukum pidana terhadap suatu tindak pidana lingkungan hidup baru dapat dimulai bila telah dilaksanakannya tindakan hukum di bawah ini:

a. Aparat yang berwenang menjatuhkan sanksi administrasi sudah menindak pelanggar dengan menjatuhkan suatu sanksi administrasi tersebut tidak mampu menghentikan pelanggaran yang terjadi; atau

b. Antara perusahaan yang melakukan pelanggaran dengan pihak masyarakat yang menjadi korban akibat terjadinya pelanggaran, sudah diupayakan penyelesaian sengketa melalui mekanisme alternatif di luar pengadilan dalam bentuk musyawarah atau perdamaian, negosiasi, atau mediasi, namun upaya yang dilakukan menemui jalan buntu; dan/atau

c. Litigasi melalui pengadilan, namun upaya tersebut juga tidak efektif, baru kegiatan dapat dimulai/instrumen penegakan hukum pidana lingkungan hidup dapat digunakan. ${ }^{8}$

Ketiga syarat asas subsidaritas dalam bentuk upaya tersebut di atas dapat dikesampingkan apabila dipenuhi tiga syarat atau kondisi tersebut di bawah ini :

a. Tingkat kesalahan pelaku relatif berat;

b. Akibat perbuatannya relatif besar;

c. Perbuatan pelaku menimbulkan keresahan masyarakat.

d. Pada surat tersebut kejaksaan menetapkan tindakan hukum tersebut bersifat alternatif, artinya tidak semua harus dijalankan cukup salah satu di antaranya.

e. Tidak dijelaskan tahapan-tahapan tersebut diperlakukan untuk delik formil atau untuk delik materiil saja. Namun dari surat tersebut dapat ditafsirkan bahwa tahapan tersebut diperuntuhkan untuk delik formil, karena terhadap tingkat kesalahan pelaku relatif berat, akibat perbuatannya relatif besar, dan perbuatan pelaku menimbulkan keresahan masyarakat prosedur tersebut dapat diabaikan.

Tindak pidana lingkungan hidup dapat dilakukan secara terus menerus jika dilihat bahwa pidana dijadikan sebagai upaya terakhir, karena yang akan terjadi adalah adanya upaya hukum lain yang hasilnya malah tidak sama sekali menghukum pembuat kerusakan. Kejahatan lingkungan dalam bentuk pencemaran dan kerusakan lingkungan, yang terjadi di Indonesia, kecenderungannya makin meningkat. ${ }^{9}$ Hal itu dapat kita ketahui dari laporan, pemberitaan media cetak, media elektronik maupun dari penglihatan langsung di lapangan. Penyelesaiannya apakah melalui tindakan preventif maupun represif, tidak bisa dipisahkan dari

\footnotetext{
Ibid, Hal 336-337.

Ibid.

9 So Woong Kim, Kebijakan Hukum Pidana Dalam Upaya Penegakan Hukum Lingkungan HIdup, Jurnal Dinamika Hukum, Vol.13 No.3, 2013, hlm. 415.
} 
instrumen penegakan hukum, apakah melalui : Penerapan Sanksi Administratif berupa Teguran Tertulis, Paksaan Pemerintah; maupun melalui jalur Penyelesaian Sengketa / Perdata ataupun penegakan hukum berupa Penegakan Hukum Pidana, berbicara mengenai penerapan hukum administratif lingkungan, tidak bisa dilepaskan dari peran Pejabat Pengawas Lingkungan Hidup (PPLH). Masalah lingkungan hidup pada dasarnya timbul karena :

a. Dinamika penduduk

b. Pemanfaatan dan pengelolaan sumber daya yang kurang bijaksana

c. Kurang terkendalinya pemanfaatan akan ilmu pengetahuan dan teknologi maju

d. Dampak negatif yang sering timbul dan kemajuan ekonomi yang seharusnya positif

e. Benturan tata ruang.

Berdasarkan hal tersebut maka diperlukan adanya AMDAL (analisis dampak lingkungan), AMDAL merupakan kajian dampak besar dan penting terhadap lingkungan hidup, dibuat pada tahap perencanaan, dan digunakan untuk pengambilan keputusan. Hal -hal yang dikaji dalam proses AMDAL: aspek fisik-kimia, ekologi, sosial ekonomi, sosial budaya, dan kesehatan masyarakat sebagai pelengkap studi kelayakan suatu rencana usaha dan/atau kegiatan. Analisis mengenai dampak lingkungan hidup di satu sisi merupakan bagian studi kelayakan untuk melaksanakan suatu rencana usaha dan/atau kegiatan, di sisi lain merupakan syarat yang harus dipenuhi untuk mendapatkan izin melakukan usaha dan/atau kegiatan. Berdasarkan analisis ini dapat diketahui secara lebih jelas dampak besar dan penting terhadap lingkungan hidup, baik dampak negatif maupun dampak positif yang akan timbul dari usaha dan/atau kegiatan sehingga dapat dipersiapkan langkah untuk menanggulangi dampak negatif dan mengembangkan dampak positif.

\section{TINDAKAN HUKUM YANG TEPAT BAGI PELAKU TINDAK PIDANA PERUSAKAN LINGKUNGAN}

\section{A. Aspek Administrasi}

Sanksi administratif merupakan tindakan hukum yang pertama diberikan terhadap perusahaan yang melakukan pencemaran dan perusakan lingkungan, Sanksi administratif mempunyai fungsi instrumental, yaitu pencegahan dan penanggulangan perbuatan terlarang dan terutama ditujukan terhadap perlindungan kepentingan yang dijaga oleh ketentuan hukum yang dilanggar tersebut. 
Penegakan hukum lingkungan dapat dilakukan secara preventif dan represif. Penegakan hukum preventif berarti pengawasan aktif dilakukan terhadap kepatuhan atas peraturan tanpa kejadian langsung yang menyangkut peristiwa konkrit yang menimbulkan dugaan bahwa peraturan hukum telah dilanggar. Upaya ini dapat dilakukan dengan pemantauan dan penggunaan kewenangan yang bersifat pengawasan (Pasal 71 ayat (1), (2) dan (3), Pasal 72, Pasal 73, Pasal 74 ayat (1), (2) dan (3), Pasal 75 UU No. 32 Tahun 2009 tentang Perlindungan dan Pengelolaan Lingkungan Hidup.

Penegakan hukum represif dilaksanakan dalam hal perbuatan melanggar peraturan dan bertujuan untuk mengakhiri secara langsung perbuatan terlarang itu.Dalam hal ini Gubernur yang berwenang melakukanya atau melalui Peraruran Daerah, Wewenang ini dapat diserahkan oleh Gubernur kepada Bupati / Walikota. Dan apabila ada pelanggaran tertentu yaitu seperti ada warga yang ternganggu kesehatannya akibat pencemaran dan atau perusakan lingkungan hidup maka Kepala Daerah atau pihak yang berkepentigan dapat mengajukan usul pencabutan izin usaha kepada pejabat yang berwenang.

UU No. 32 Tahun 2009 tentang Perlindungan dan Pengelolaan Lingkungan Hidup Pasal 76 ayat ( 2 ) Sanksi administratif terdiri atas:

a. Teguran tertulis.

b. Paksaan Pemerintah.

c. Pembekuan izin lingkungan.

d. Pencabutan izin lingkungan.

Pasal 80 ayat ( 1 ) Paksaan Pemerintah sebagaimana dimaksud dalam pasal 76 ayat ( 2 ) huruf b berupa :

a. Penghentian sementara kegiatan produksi.

b. Pemindahan sarana produksi.

c. Penutupan saluran pembuangan air limbah atau emisi.

d. Pembongkaran.

e. Penyitaan terhadap barang atau alat yang berpontensi menimbulkan pelanggaran.

f. Penghentian sementara seluruh kegiatan.

g. Tindakan lain yang bertujuan untuk menghentikan pelanggaran dan tindakan memulihkan fungsi lingkungan hidup.

Disamping pengawasan administratif, kepada pengusaha hendaknya ditanamkan konsep pencegahan pencemaran menguntungkan (Polition Provention Pays). Konsep ini yaitu menekankan kepada upaya pencegahan pencemaran atau perusakan lingkungan hidup dalam proses produksi dengan penerapkan teknologi lebih bersih sehingga tercapai peningkatan efisiensi dan efektifitas produksi yang kemudian meningkatkan keuntungan perusahaan disamping ikut menjaga lingkungan hidup 


\section{B. Aspek Pidana}

Sanksi pidana merupakan aspek tindakan hukum yang terakhir. Sanksi pidana diberikan terhadap perusahaan yang melakukan pencemaran dan perusakan lingkungan, mempunyai fungsi untuk mendidik perusahaan sehubungan dengan perbuatan yang dilakukan, terutama ditujukan terhadap perlindungan kepentingan umum yang dijaga oleh ketentuan hukum yang dilanggar tersebut. Selain itu fungsinya juga untuk mencegah atau menghalangi pelaku pontensial agar tidak melakukan perilaku yang tidak bertanggung jawab terhadap lingkungan hidup.

Untuk bisa menjatuhkan pidana untuk kasus lingkungan pada perusahaan maka juga berlaku peraturan-peraturan seperti kasus pidana lainnya yaitu asas legalitas maksudnya harus berdasarkan hukum yang ada pada saat perbuatan itu dilakukan dan harus terbukti kesalahannya. Ketentuan pidana tercantum dalam BAB XV UU No. 32 Tahun 2009 tentang Perlindungan dan Pengelolaan Lingkungan Hidup yang terdiri dari Pasal 97 sampai dengan Pasal 120.

Pasal 98 UU No. 32 Tahun 2009 tentang Perlindungan dan Pengelolaan Lingkungan Hidup menyatakan:

1) Setiap orang yang dengan sengaja melakukan perbuatan yang mengakibatkan dilampauinya baku mutu udara, baku mutu ambien, baku mutu air, baku mutu air laut, atau kriteria baku kerusakan lingkungan hidup, dipidana dengan penjara paling singkat 3 (tiga) tahun dan paling lama 10 (sepuluh) tahun dan denda paling sedikit Rp 3.000.000.000,00 (tiga miliar rupiah) dan paling banyak Rp 10.000.000.000,00 (sepuluh miliar rupiah).

2) Apabila perbuatan sebagaimana dimaksud pada ayat (1) mengakibatkan orang luka dan/atau bahaya kesehatan manusia, dipidana dengan pidana penjara palingsingkat 4 (empa) tahun dan paling lama 12 (dua belas) tahun dan denda paling sedikit $\mathrm{Rp}$ 4.000.000.000,00 (empat miliar rupiah) dan paling banyak $\mathrm{Rp}$ 12.000.000.000,00 (dua belas miliar rupiah).

3) Apabila perbuatan sebagaimana dimaksud pada ayat (1) mengakibatkan orang luka berat atau mati, dipidana dengan pidana penjara paling singkat 5 ( lima ) tahun dan paling lama 15 (lima belas) tahun dan denda paling sedikit Rp 5.000.000.000,00 (lima miliar rupiah) dan paling banyak Rp 15.000.000.000,00 (lima belas miliar rupiah).

Apabila tindak pidana lingkungan hidup dilakukan oleh atas nama badan usaha atau perusahaan maka tuntutan pidana dan sanksi pidana dijatuhkan kepada badan usaha atau orang yang memberi perintah untuk melakukan tindak pidana tersebut atau orang yang bertindak sebagai pemimpin kegiatan dalam tindak pidana tersebut ( Pasal 116 ayat ( 1 ) dan ( 2 ) UU No. 32 Tahun 2009 tentang Perlindungan dan Pengelolaan Lingkungan Hidup ). 
Ancaman pidana sebagaimana tercantum dalam pasal-pasal UU No. 32 Tahun 2009 tentang Perlindungan dan Pengelolan Lingkungan Hidup adalah pidana penjara dan denda. Selain itu ada pidana tambahan atau tindakan tata tertib terhadap badan usaha Pasal 119 UU No.32 Tahun 2009 berupa :

a. Perampasan keuntungan yang diperoleh dari tindak pidana.

b. Penutupan seluruh atau sebagian tempat usaha dan / atau kegiatan.

c. Perbaikan akibat tindak pidana.

d. Pewajiban mengerjakan apa yang dilalaikan tanpa hak.

e. Penempatan Perusahaan dibawah pengampuan paling lama 3 (tiga) tahun.

\section{PENYELESAIAN HUKUM PIDANA LINGKUNGAN BERDASARKAN UNDANG-UNDANG NOMOR 32 TAHUN 2009 TENTANG PERLINDUNGAN DAN PENGELOLAAN LINGKUNGAN HIDUP (DITERAPKAN PADA KASUS PT INDONESIA POWER)}

Penyusun Undang-Undang tentang Perlindungan dan Pengelolaan Lingkungan Hidup, berusaha untuk membuat definisi tentang lingkungan sebagai berikut:

"lingkungan hidup adalah kesatuan ruang dengan semua benda, daya, keadaan, dan makhluk hidup, termasuk manusia dan perilakunya, yang mempengaruhi alam itu sendiri, kelangsungan perikehidupan dan kesejahteraan manusia serta makhluk hidup lain." 10

Istilah lingkungan dan lingkungan hidup atau lingkungan hidup manusia sebagai terjemahan dari bahasa Inggris environment and human environment. Sering kali digunakan secara silih berganti dalam pengertian sama. Sekalipun arti lingkungan dan lingkungan hidup manusia dapat diberi batasan yang berbeda-beda berdasarkan persepsi setiap penulis. ${ }^{11}$ Dalam pengkajian terhadap ketentuan pemidanaan tindak kejahatan lingkungan, terlebih dahulu perlu dipahami apakah yang dimaksud dengan pidana dan pemidanaan tersebut, kemudian dilanjutkan makna filosofis yang terkandung dalam ketentuan-ketentuan pemidanaan

10 Undang-Undang Nomor 32 Tahun 2009 tentang Perlindungan dan Pengelolaan Lingkungan Hidup Pasal 1 ayat (1).

11 Daud Silalahi, Hukum Lingkungan Dalam Sistem Penegakan Hukum Lingkungan Indonesia. Bandung. Alumni. 1992. Hal 7. 
yang berlaku (ius constitutum). Menurut Soedarto yang dimaksud dengan pidana adalah penderitaan yang sengaja dibebankan kepada orang yang melakukan perbuatan yang memenuhi syarat-syarat tertentu.

Dari pengertian di atas dapat disimpulkan bahwa pidana mengandung unsur-unsur atau ciri-ciri sebagai berikut: ${ }^{12}$

1) pidana itu pada hakikatnya merupakan suatu pengenaan penderitaan atau nestapa atau akibat lain-lain yang tidak menyenangkan;

2) pidana itu diberikan dengan sengaja oleh seseorang atau badan yang mempunyai kekuasaan (oleh pihak yang berwenang);

3) pidana itu dikenakan kepada seseorang yang telah melakukan tindak pidana menurut undang-undang. Sementara pembatasan makna untuk pengertian pemidanaan menjadi suatu pengertian yang dilematis, terutama dalam menentukan apakah pemidanaan ditujukan untuk melakukan pembalasan atas tindak pidana yang terjadi atau merupakan tujuan yang layak dari proses pidana adalah pencegahan tingkah laku yang anti sosial. Menentukan titik temu dari dua pandangan tersebut, jika tidak berhasil dilakukan, memerlukan rumusan baru dalam sistem atau tujuan pemidanaan dalam hukum pidana. Pemidanaan mempunyai beberapa tujuan yang bisa diklasifikasikan berdasarkan teori- teori tentang pemidanaan. Teori tentang tujuan pemidanaan berkisar pada perbedaan hakikat ide dasar tentang pemidanaan, dapat dilihat dari beberapa pemandangan.

Keberadaan hukum lingkungan dimaksudkan untuk melindungi dan mengamankan kepentingan alam dari kemerosotan mutu dan kerusakannya dalam rangka menjaga kelestariannya. ${ }^{13}$ Hukum acara yang digunakan dalam peradilan tindak pidana lingkungan tidak beda dengan peradilan pidana pada umumnya, namun yang membedakan adalah esensi yang harus dimengerti oleh penegak hukum yang sampai saat ini belum bisa dipahami oleh para penegak hukum lingkungan di Indonesia. Undang-Undang Nomor 32 Tahun 2009 tentang Perlindungan dan Pengelolaan Lingkungan Hidup sebagai sumber formal utama hukum lingkungan di Indonesia selain memuat ketentuan-ketentuan hukum dan instrumen-instrumen hukum seperti yang terkandung dalam undang-undang sebelumnya yaitu Undang-Undang Lingkungan Hidup tahun 1982 dan Undang-Undang Lingkungan Hidup tahun 1997 telah juga memuat norma-norma dan instrumen-instrumen hukum baru. Beberapa norma hukum baru yang penting adalah tentang perlindungan hukum atas tiap orang yang memperjuangkan hak atas lingkungan hidup, kewenangan Pejabat Penyidik Pegawai Negeri Sipil (PPNS) dan penciptaan delik-delik materiil baru. Dalam tulisan ini beberapa norma hukum baru yang akan diuraikan. ${ }^{14}$ Undang-Undang Nomor 32 Tahun

12 Muladi dan Barda Nawawi Arief, Teori-Teori dan Kebijakan Pidana, Alumni, Bandung, 2005, hal 4.

13 Gatot P Soemartono, Hukum Lingkungan Indonesia, Sinar Grafika, Jakarta, 1996, Hal 25.

14 http://www.mahkamahagung.go.id, di unduh tanggal 26 September 2014. 
2009 tentang Perlindungan dan Pengelolaan Lingkungan Hidup telah secara tegas mengadopsi asas-asas yang terkandung dalam Delarasi Rio 1992, yaitu asas-asas tanggungjawab negara, keterpaduan, kehati-hatian, keadilan, pencemar membayar, partisipatif dan kearifan lokal. Pengadopsian ini merupakan politik hukum yang penting karena dapat memperkuat kepentingan pengelolaan lingkungan hidup manakala berhadapan dengan kepentingan ekonomi jangka pendek. Hakim dalam mengadili sebuah perkara dapat menggunakan asas-asas itu untuk memberikan perhatian atas kepentingan pengelolaan lingkungan hidup yang mungkin tidak diperhatikan oleh pelaku usaha ataupun pejabat pemerintah yang berwenang.

Undang-Undang Nomor 32 Tahun 2009 tentang Perlindungan dan Pengelolaan Lingkungan Hidup khususnya dengan Pasal 66 sangat maju dalam memberikan perlindungan hukum kepada orang yang memperjuangkan hak atas lingkungan hidup dari kemungkinan tuntutan pidana dan perdata. Perlindungan hukum ini sangat penting karena pada masa lalu telah ada kasus-kasus di mana para aktivis lingkungan hidup yang melaporkan dugaan terjadinya pencemaran dan perusakan lingkungan hidup telah digugat secara perdata atau dituntut secara pidana atas dasar pencemaran nama baik perusahaan-perusahaan yang diduga telah menimbulkan pencemaran atau perusakan lingkungan hidup. Di dalam sistem hukum Amerika Serikat dan Phillipina, jaminan perlindungan hukum seperti ini disebut dengan Anti SLAPP (strategic legal action against public participation), yaitu gugatan yang dilakukan oleh perusahaan yang diduga telah mencemari atau merusak lingkungan hidup kemudian menggugat si pelapor atau pemberi informasi atau whistle blower dugaan terjadinya masalah-masalah lingkungan dengan tujuan untuk menimbulkan rasa takut dan kerugian materiil terhadap pelapor atau pemberi informasi maupun terhadap pihak-pihak lain di masa datang.

Gugatan SLAPP dapat mematikan keberanian anggota-anggota masyarakat untuk bersikap kritis dan menyampaikan laporan atau informasi tentang dugaan atau telah terjadinya masalah-masalah lingkungan hidup oleh sektor-sektor usaha sehingga pada akhirnya dapat menggagalkan pengelolaan lingkungan hidup yang melibatkan peran aktif masyarakat madani (civil socitey). Para hakim di Indonesia penting sekali untuk memahami kehadiran dan kegunaan Pasal 66 UndangUndang Nomor 32 Tahun 2009 tentang Perlindungan dan Pengelolaan Lingkungan Hidup.

Undang-Undang Nomor 32 Tahun 2009 tentang Perlindungan dan Pengelolaan Lingkungan Hidup telah menimbulkan perubahan dalam bidang kewenangan penyidikan dalam perkara-perkara lingkungan. Berdasarkan Pasal6 ayat (1) Kitab Undang-Undang Hukum Acara Pidana (KUHAP), penyidik adalah pejabat Polisi Negara Republik Indonesia (seterusnya disingkat dengan Polri) dan pejabat Pegawai Negeri Sipil (seterusnya disingkat dengan PPNS) tertentu yang diberi wewenang khusus oleh undang-undang. Undang-Undang Nomor 32 
Tahun 2009 tentang Perlindungan dan Pengelolaan Lingkungan Hidup merupakan salah satu undang-undang sebagaimana dimaksud Pasal 6 ayat (1) yang menjadi dasar bagi keberadaan PPNS sebagaimana dirumuskan dalam Pasal Kewenangan Polri selain sebagaimana disebutkan dalam Pasal 7 ayat (1) KUHAP, antara lain, melakukan penangkapan, penahanan, penggeledahan, dan penyitaan, pemeriksaan dan penyitaan surat dan wewenang koordinasi atas pelaksanaan tugas PPNS (Pasal 7 ayat (2), Polri sebagai institusi yang berwenang menyerahkan berkas perkara kepada penuntut umum (Pasal8 ayat (2).

Dengan demikian, berdasarkan sistem KUHAP, PPNS tidak berwenang menyerahkan berkas hasil penyidikan secara langsung kepada penuntut umum, tetapi harus melewati Polri. Undang-Undang Nomor 32 Tahun 2009 tentang Perlindungan dan Pengelolaan Lingkungan Hidup telah mengubah ketentuan yang selama ini memberikan kewenangan kepada Polri sebagai institusi satu-satunya yang dapat menyerahkan berkas hasil penyidikan kepada penuntut umum sebagaimana dinyatakan dalam Pasa 18 ayat (2) KUHAP. Dengan diundangkannya Undang-Undang Nomor 32 Tahun 2009 tentang Perlindungan dan Pengelolaan Lingkungan Hidup telah menimbulkan perubahan. Perubahan ini terjadi melalui Pasal 94 ayat (6) UndangUndang Nomor 32 Tahun 2009 tentang Perlindungan dan Pengelolaan Lingkungan Hidup yang menyatakan: "hasil penyidikan yang telah dilakukan oleh penyidik pegawai negeri sipil disampaikan kepada penuntut umum." Dengan demikian, Penyidik Pegawai Negeri Sipil (PPNS) lingkungan hidup dapat dan berwenang untuk menyerahkan berkas hasil penyidikan secara langsung kepada penuntut umum tanpa melalui Polri lagi. Pemberian kewenangan ini memang masih harus dibuktikan secara empiris pada masa depan apakah akan membawa perkembangan positif bagi upaya penegakan hukum lingkungan pidana atau tidak membawa perubahan apapun.

Hal ini jika diaplikasikan terhadap kasus yang terjadi pada PT Indonesia Power yang sampai mengakibatkan bocornya pipa minyak dan kebocoran ini berdampak pada pencemaran lingkungan parah, karena sudah sampai mencemari air laut dan tanaman bakau di kawasan Pelabuhan Benoa, Kota Denpasar dan Indonesia Power tidak serius terhadap menanggulangi pencemaran lingkungan tersebut, karena pencemaran lingkungan itu bentuk dari pelanggaran undangundang lingkungan hidup. Pihak Indonesia Power tampaknya hanya seremonial dan sekedar saja membersihkan sisa oli dari kebocoran pipanya sebagaimana dituduhkan oleh Yayasan Wisnu Bali maka berdasarkan Pasal 66 Undang-Undang Nomor 32 Tahun 2009 tentang Perlindungan dan Pengelolaan Lingkungan Hidup memberikan perlindungan hukum kepada Yayasan Wisnu Bali yang telah memperjuangkan hak atas lingkungan hidup dari kemungkinan tuntutan pidana dan perdata atas pencemaran nama baik dari PT Indonesia Power. Sehingga Yayasan Wisnu Bali dapat mengadukannya kepada PPNS, karena PPNS yang mempunyai kewenangan atas hal tersebut, hal ini 
didasarkan pada Pasal 6 ayat (1) yang menjadi dasar bagi keberadaan PPNS. Ide dasar penerapan sanksi pidana dan tindakan dalam UndangUndang Nomor 23 tahun 2009 tentang perlindungan dan pengelolaan lingkungan hidup karena lingkungan sebagai tempat tinggal makhluk hidup terutama manusia yang memiliki lebih banyak kepentingan dengan lingkungan perlu diatur mengenai penggunaan lingkungan agar lingkungan tidak dieksploitasi secara berlebihan sehingga dapat merusak lingkungan dan nantinya akan merugikan manusia sendiri. ${ }^{15}$

Berdasarkan Pasal 116 dan Pasal 118 Undang-Undang Nomor 32 Tahun 2009 tentang Perlindungan dan Pengelolaan Lingkungan Hidup dapat diketahui bahwa ada tiga pihak yang dapat dikenai tuntutan dan hukuman ada tiga pihak yaitu:

a. badan usaha itu sendiri;

b. orang yang memberi perintah atau yang bertindak sebagai pemimpin dalam tindak pidana;

c. pengurus.

Mengingat Pasal 118 Undang-Undang Nomor 32 Tahun 2009 tentang Perlindungan dan Pengelolaan Lingkungan Hidup yang menyebutkan "sanksi dikenakan terhadap badan usaha yang diwakili oleh pengurus yang berwenang mewakili di dalam dan di luar pengadilan sesuai dengan peraturan perundang-undangan selaku pelaku fungsional", pengurus tetap juga dapat dikenai pertanggungjawaban atas dasar kriteria "orang yang memberi perintah atau orang yang bertindak sebagai pemimpin dalam tindak pidana" sebagaimana dirumuskan dalam Pasal 116 ayat (1) huruf b. Perbedaannya adalah rumusan Pasal 116 ayat (1) huruf $\mathrm{b}$ memang mengharuskan penyidik dan penuntut umum untuk membuktikan bahwa penguruslah yang telah bertindak sebagai orang yang memberi perintah atau yang bertindak sebagai pemimpin dalam tindak pidana, sehingga memerlukan kerja keras penyidik dan penuntut umum untuk membuktikan peran para pengurus dalam tindak pidana lingkungan.

Sebaliknya, menurut ketentuan Pasal 116 ayat (1) huruf b dikaitkan dengan Pasal 118, pengurus karena jabatannya secara serta merta atau otomatis memikul pertanggungjawaban pidana, sehingga lebih memudahkan dalam upaya penuntutan karena tidak membutuhkan pembuktian peran para pengurus secara spesifik dalam sebuah peristiwa pidana lingkungan. Penjelasan Pasal 118 Undang-Undang Nomor 32 Tahun 2009 tentang Perlindungan dan Pengelolaan Lingkungan Hidup memperkuat interpretasi bahwa jika badan usaha melakukan pelanggaran pidana lingkungan, tuntutan dan hukuman "dikenakan terhadap pimpinan badan usaha atas dasar pimpinan perusahaan yang memiliki kewenangan terhadap pelaku fisik dan menerima tindakan tersebut". Pengertian "menerima tindakan tersebut" adalah "menyetujui, membiarkan atau tidak cukup melakukan pengawasan terhadap tindakan

15 Dwi Wiharyangti, Impementasi Sanksi Pidana dan Sanksi Tindakan Dalam Kebijakan Hukum Pidana Indonesia, Pandecta, Vol. 6 No.1, Januari 2011, hlm. 83. 
pelaku fisik, atau memiliki kebijakan yang memungkinkan terjadinya tindak pidana tersebut." Dengan demikian, pengurus perusahaan yang mengetahui dan membiarkan karyawan perusahaan melepas pembuangan limbah tanpa melalui pengolahan dianggap melakukan tindak pidana atas nama badan usaha, sehingga dirinya harus bertanggung jawab.

\section{KASUS ILLEGAL LOGGING DI PONTIANAK}

Dalam kasus ini, yaitu terdakwa an. Tian Hartono alias Buntia selaku Direktur PT. Rimba Kapuas Lestari yang bersama - sama Ir. H. Gusti Sofyan Afsier, MM selaku Kepala Dinas Kehutanan dan Perkebunan Kabupaten Sintang dan Drs. Elyakim Simon Djalil, MM., selaku Bupati Sintang Propinsi Kalimantan Barat didakwa telah melakukan tindak pidana dan dipersalahkan karena melakukan pelanggaran sebagai berikut: berikut:

Adapun alasan dakwaan penuntut umum antara lain sebagai

(1) Membuat dan merekayasa peta RKT yang tidak didaftarkan pada Dinas Areal Kerja sehingga aktivitas kegiatan pemanfaatan hasil hutan kayu yang dilakukannya memasuki areal kawasan Hutan Produksi dan bahkan merambah ke dalam kawasan Hutan Lindung;

(2) Melakukan penebangan kayu tanpa izin di kawasan Hutan Lindung dengan menggunakan tenaga masyarakat di sekitar hutan dengan cara memberikan bayaran/upah borongan sehingga dari keadaan tersebut telah merugikan negara; dan

(3) Memasukkan alat - alat berat dalam kawasan Hutan Negara tanpa izin, serta menguasai sejumlah batang kayu bulat tanpa dilengkapi surat keterangan yang sah.

Mereka didakwa telah melakukan kegiatan penebangan tegalan kayu jenis Meranti di kawasan Hutan Negara Lubuk Lintang Kabupaten Sintang dengan mendasarkan surat Izin Bupati Sintang Nomor 184 Tahun 2002 tanggal 14 Mei 2002 di wilayah Kecamatan Kepauk Belimbing dan Kecamatan Ambalan - Kabupaten Sintang seluas kurang lebih 41.090 Hektar.

Dalam praktek putusan di pengadilan dijumpai adanya kesamaan dengan kasus yang terjadi di Pengadilan Negeri Padang, Sumatra Barat. Pengadilan Negeri Pontianak,dengan surat putusan nomor. 107/Pid B/2006/PN PTK tanggal 21 Desember 2006 memutuskan bahwa "terdakwa tidak terbukti bersalah melakukan tindakan pidana seperti yang didakwakan kepadanya. Namun, untuk sebagian dari perbuatan terdakwa, hakim menyatakan bersalah oleh karena terdakwa, dalam beberapa unsur perbuatannya terbukti tidak memperoleh surat perizinan dari pejabat yang berwenang. Terdakwa dinyatakan bersalah karena terbukti membawa masuk alat - alat berat ke dalam kawasan Hutan 
Negara. Sehingga kepada yang bersangkutan dijatuhi hukuman 2 tahun penjara dan denda sebesar 1 Miliyard Rupiah dengan pengganti denda sebesar 4 bulan kurungan, serta biaya perkara sebesar Rp. 10.000,ditanggungkan kepada terdakwa dsn terhadap keseluruhan barang bukti perkara dikembalikan kepada terdakwa.

\section{KESIMPULAN}

Kaidah dasar yang melandasi pembangunan dan perlindungan lingkungan hidup Indonesia terdapat dalam pembukaan Undang-Undang Dasar 1945 pada alinea ke-4 yang pada pokoknya mewajibkan pemerintah untuk mendayagunakan sumber daya alam yang ada untuk sebanyak-banyak kesejahteraan rakyat. Pemikiran tentang kewajiban negara ini secara konstitusional tersebut lebih dijabarkan lagi dalam Pasal 33 Undang-Undang Dasar 1945, yaitu prinsip negara, bumi dan segala kekayaan yang terkandung di dalamnya serta menjadi hajat hidup orang banyak dikuasai oleh negara untuk digunakan untuk kehidupan orang banyak atau dengan kata lain negara bertindak sebagai penyelenggara kepentingan umum.

Kaidah dasar yang melandasi pembangunan dan perlindungan lingkungan hidup Indonesia terdapat dalam pembukaan Undang-Undang Dasar 1945 pada alinea ke-4 yang pada pokoknya mewajibkan pemerintah untuk mendayagunakan sumber daya alam yang ada untuk sebanyak-banyak kesejahteraan rakyat. Pemikiran tentang kewajiban negara ini secara konstitusional tersebut lebih dijabarkan lagi dalam Pasal 33 Undang-Undang Dasar 1945, yaitu prinsip negara, bumi dan segala kekayaan yang terkandung di dalamnya serta menjadi hajat hidup orang banyak dikuasai oleh negara untuk digunakan untuk kehidupan orang banyak atau dengan kata lain negara bertindak sebagai penyelenggara kepentingan umum

Keberadaan hukum lingkungan dimaksudkan untuk melindungi dan mengamankan kepentingan alam dari kemerosotan mutu dan kerusakannya dalam rangka menjaga kelestariannya. Sanksi pidana merupakan aspek tindakan hukum yang terakhir. Sanksi pidana diberikan terhadap perusahaan yang melakukan pencemaran dan perusakan lingkungan, mempunyai fungsi untuk mendidik perusahaan sehubungan dengan perbuatan yang dilakukan, terutama ditujukan terhadap perlindungan kepentingan umum yang dijaga oleh ketentuan hukum yang dilanggar tersebut. Selain itu fungsinya juga untuk mencegah atau menghalangi pelaku pontensial agar tidak melakukan perilaku yang tidak bertanggung jawab terhadap lingkungan hidup. Hukum acara yang digunakan dalam peradilan tindak pidana lingkungan tidak beda dengan peradilan pidana pada umumnya, namun yang membedakan adalah esensi yang harus dimengerti oleh penegak hukum yang sampai saat ini belum bisa dipahami oleh para penegak hukum lingkungan di Indonesia Untuk bisa menjatuhkan pidana untuk kasus lingkungan pada perusahaan 
maka juga berlaku peraturan-peraturan seperti kasus pidana lainnya yaitu asas legalitas maksudnya harus berdasarkan hukum yang ada pada saat perbuatan itu dilakukan dan harus terbukti kesalahannya.

\section{REFERENSI}

Sunarso, Siswanto. Hukum Pidana Lingkungan Hidup dan Strategi Penyelesaian Sengketa. Rineka Cipta; Jakarta. 2005.

Machmud, Syahrul. Problematika Penerapan Delik Formil Dalam Perspektif Penegakan Hukum Pidana Lingkungan Di Indonesia. Mandar Maju; Bandung. 2012.

Silalahi, Daud. Hukum Lingkungan Dalam Sistem Penegakan Hukum Lingkungan Indonesia. Bandung; Alumni. 1992.

Muladi dan Barda Nawawi arief. Teori-Teori dan Kebijakan Pidana. Alumni; Bandung, 2005.

P Soemartono, Gatot. Hukum Lingkungan Indonesia. Sinar Grafika; Jakarta. 1996.

Fahmi, Sudi. 2011. Asas Tanggung Jawab Negara Sebagai Dasar Pelaksanaan Perlindungan dan Pengelolaan Lingkungan Hidup : Jurnal Hukum Volume 18 Nomor 2 ( halaman 212-228 ).

Kim, So Woong. 2013. Kebijakan Hukum Pidana Dalam Upaya Penegakan Hukum Lingkungan Hidup : Jurnal Dinamika Hukum Volume 13 Nomor 3 ( halaman 415).

Wiharyangti, Dwi. 2011. Implementasi Sanksi Pidana dan Sanksi Tindakan Dalam Kebijakan Hukum Pidana : Pandecta Volume 6 Nomor 1 ( halaman 83 ).

Palmer, Kenneth, "Environmental Management of Oil and Gas Activities in the Exclusive Economic Zone and Continental Shelf of New Zealand". J. Energy \& Nat. Resources L. Vol. 31. No. 2. May 2013. 
Aji, Wiyatno, Arifin, \& Kamal

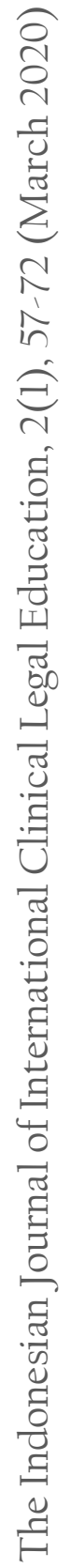

